\title{
PENATALAKSANAAN PASIEN DEPRESI MAYOR DI RSJ PROF. DR. SOEROYO MAGELANG DENGAN MENGGUNAKAN REPETITIVE TRANSCRANIAL MAGNETIC STIMULATION (rTMS)
}

\author{
Anang Widyanta, Edith Humris, Ratna Dewi, Ni Kadek Duti \\ Rumah Sakit Jiwa Prof. Dr. Soerojo Magelang \\ Korespondensi: intisardani@gmail.com
}

\begin{abstract}
ABSTRAK
Gangguan depresi mayor merupakan gangguan kejiwaan yang membawa dampak sangat buruk pada kehidupan penderita dan lingkungannya. Berbagai metode dikembangkan dalam memberikan penatalaksanaannya, seperti obat, psikoterapi, Electroconvulsive Therapy (ECT). Repetitive Transcranial Magnetic Stimulation saat ini dikembangkan sebagai salah satu alternative pengobatan gangguan depresi mayor. Pada penelitian ini digunakan Hamilton Rating Scale for Depression (HAM-D).
\end{abstract}

Kata Kunci: Depresi Mayor, Electroconvulsive Therapy, Repetitive Transcranial Magnetic Stimulation, Hamilton Rating Scale for Depression D 


\title{
MANAGEMENT OF MAJOR DEPRESSION PATIENTS IN PSYCHIATRIC HOSPITAL OF DR. SOEROYO MAGELANG USING REPETITIVE TRANSCRANIAL MAGNETIC STIMULATION (rTMS)
}

E Anang Widyanta, Edith Humris P, Ratna Dewi P, Ni Kadek Duti ASPL. Mental Hospital Prof. Dr. Soerojo Magelang

Correspondence: intisardani@gmail.com

\begin{abstract}
Major depressive disorder is a psychiatric disorder that brings a very bad impact on the life of the patient and his environment. Various methods are developed in providing management, such as medicine, psychotherapy, Electroconvulsive Therapy (ECT). Repetitive Transcranial Magnetic Stimulation currently developed as an alternative treatment of major depressive disorders. In this study used Hamilton Rating Scale for Depression (HAM-D).
\end{abstract}

Keywords: Major Depression, Electroconvulsive Therapy, Repetitive Transcranial Magnetic Stimulation, Hamilton Rating Scale for Depression D 


\section{PENDAHULUAN}

Depresi merupakan satu masa terganggunya fungsi manusia yang berkautan dengan alam perasaan sedih dan gejala penyertanya. ${ }^{1}$ Bila kondisi depresi seseorang menyebabkan terganggunya fungsi aktivitas sehari-hari, maka hal tersebut dapat disebut sebagai Depresi Mayor. Dalam Diagnostic and Statistical Manual of Mental Disorders V (DSM-V) gangguan terjadi paling tidak selama 2 minggu dengan gejala: mood depresi, kehilangan kesenangan, penurunan berat badan, gangguan tidur, kelelahan, merasa tidak berharga dan bersalah, gangguan konsentrasi, dan muncul keinginan untuk bunuh diri. ${ }^{2}$

Gangguan ini merupakan problem kesehatan yang cukup serius, berdasarkan prevalensinya terjadi $20 \%$ pada wanita dan $12 \%$ pada pria. ${ }^{3}$ WHO juga memperkirakan pada tahun 2020 akan menempati urutan ke-2 penyakit di dunia, bahkan pada tahun 2030 diperkirakan menempati urutan pertama beban penyakit. ${ }^{4}$

Penyebab depresi meliputi ketidakseimbangan biogenik amin, gangguan neuroendokrin, perubahan neurofisiologi, factor psikologis, serta faktor-faktor lain yang diduga berperan dalam terjadinya depresi. ${ }^{5}$

Penatalaksanaan gangguan ini biasaanya menggunakan obat, psikoterapi, kombinasi obat dan psikoterapi, serta terapi kejut listrik. ${ }^{6}$ Repetitive Transcranial Magnetic Stimulation (rTMS) merupakan alat yang juga direkomendasikan untuk pengobtan depresi mayor, karena rTMS mempunyai kemampuan sebagai antidepresan. 7,8

Penggunaan rTMS pada area dorsolateral prefrontal kortek kiri (Left Dorsolateral Prefrontal Cortex/ LDLPFC) dengan frekwensi tinggi dan area dorsolateral prefrontal kanan (Right Dorsolateral Prefrontal Cortex)
RDLPFC) dengan frekwesi rendah dinyatakan dapat memberikan perbaikan pada gangguan depresi. ${ }^{9,10}$

\section{METODE}

Penatalaksanaan depresi dilakukan pada 5 pasien rawat inap di RSJ. Prof. dr. Soeroyo Magelang yang telah ditegakkan diagnoasa Depresi Mayor berdasarkan kriteria DSM V. Masing-masing pasien akan mendapatkan terapi rTMS sebanyak 15 kali dan akan mendapatkan injeksi secara intramuscular Haloperidol $5 \mathrm{mg}$ per 12 jam serta Injeksi Diazepam 1 ampul (10 mg) bila malam hari diperlukan. Secara per oral diberikan tablet Risperidon 2 mg setiap 12 jam dan Trihexyphenidil $2 \mathrm{mg}$ setiap 12 jam.

Dalam penelitian ini, lokasi yang diberikan stimulai rTMS adalah pada area dorsolateral prefrontal kortek kiri dengan frekuensi $20 \mathrm{~Hz}$ dengan power $100 \%$ selama 20 menit. Lokasi lainnya adalah pada area area dorsolateral prefrontal kanan $1 \mathrm{~Hz}$ dengan power $100 \%$ selama 30 menit.

Pengukuran tingkat keberhasilan penatalaksanaan pada pasien dilakukan dengan menggunakan Hamilton Depression Rating Scale (HAM-D). Pengukuran dilakukan 3 kali. Pengukuran I Dilakukan pada hari ke-3 setelah dilakukan pengamatan selama rawat inap sebagai baseline. Pengukuran II dilakukan 1 hari setelah rTMS terakhir dan pengukuran III dilakukan 10 hari setelah rTMS terakhir.

\section{TUJUAN PENELITIAN}

Mengetahui tingkat keberhasilan penatalaksanaan pasien depresi mayor di RSJ.Prof.dr.Soeroyo Magelang dengan menggunakan Repetitive Trancranial Magnetic Stimulation (rTMS) sebagai pengganti obat antidepresan. 


\section{HASIL DAN PEMBAHASAN}

\section{PASIEN I, Ny S (52 tahun)}

Dirawat dengan keluhan utama merasa sedih, bingung, tak bisa tidur, tak bersemangat. Dimana pasien sekitar 2 bulan yang lalu merasa bingung, sedih, sulit konsentrasi, tidak semangat, mudah lapar, sering lemes, sulit tidur. Pasien juga merasa bersalah dan berdosa terhadap suami. Mendengar suara menyalahkan, mengomentari buruk tentang pasien. Pasien mencoba sering ikut mengaji tapi malah tambah bingung karena rasa berdosanya meningkat. 2 minggu terakhir pasien tidak bisa konsentrasi sehingga pekerjaan rumah terbengkalai. Tak punya inisiatif mau melakukan apa pasien jadi malu bergaul dan sering melamun.

Setelah dilakukan penatalaksanaan sesuai protokol, maka didapatkan nilai HAM-D I: 27, HAMD II: 17, dan HAM-D III: 10.

\section{PASIEN II, Sdr AA (16 tahun)}

Dirawat dengan keluhan utama karena merasa bingung. Sekitar: 1 bulan yang lalu pasien merasa bingung, sering merasa bersalah tidak percaya diri, merasa tidak mampu mengikuti kegiatan sekolah dan aktivitas lainnya, mudah lelah, sering lemas, sulit mereasa senang. Pasien juga mengeluhkan nafsu makan menjadi berkurang dan tidur sering terbangun pada malam hari. Selain itu pasien mengeluhkan juga sering mendengar suara-suara tanpa sumber yang jelas yang menyalahkan dirinya. Aktivitas sehari-hari seperti makan dan mandi harus dibantu keluarganya. Seharihari pasien hanya mengurung diri di kamar, sering melamun dan menangis tanpa sebab. Pasien akhirnya tidak mau berangkat sekolah.

Setelah dilakukan penatalaksanaan sesuai protokol, maka didapatkan nilai HAM-D I: 28, HAMD II: 8, dan HAM-D III: 4.

\section{PASIEN III, Sdr FA (17 tahun)}

Pasien dirawat dengan

keluhun utama murung dan tidak bersemangat. Sekitar: 6 Bulan yang lalu pasien sering mengeluh merasa pusing, badan tidak nyaman, banyak keluhan fisik seperti: linu-linu, mual, nafsu makan turun, sulit tidr, tidak semangat, sulit merasa senang. Sekitar 3 bulan kemudian pasien mengeluh lemas, tidak ada gairah hidup sering merasa bersalah dan berdosa. Bahkan terdapat suarasuara tanpa sumber yang diduga di telingga yang membuat dia bingung dan sedih. Akhirnya pasien merasa bosan hidup akan tetapi tidak ada niatan untuk mengakhiri hidup. Aktifitas sehari-hari seperti makan, minum, mandi perawatan diri harus diingatkan. Saat ini pasien sering melamun dan mengurung diri di kamar, tidak mau keluar rumah, serta tidak mau bekerja.

Setelah dilakukan penatalaksanaan sesuai protokol, maka didapatkan nilai HAM-D I: 27, HAMD II: 20, dan HAM-D III: 12 .

\section{PASIEN IV, Sdr AW (19 tahun)}

Keluhan utama pada pasien ini adalah mengurung diri, dimana sekitar satu bulan sebelumnya pasien menjadi banyak diam, malas beraktifitas, sulit merasa senang, perasaan menjadi sedih. Disamping itu pasien merasa bersalah, merasa berdosa, sulit tidur, merasa putus asa, dan merasa hidupnya sangat menderita, akan tetapi ada keinginan untuk melakukan tindakan bunuh diri. Ada suara-suara tanpa sumber yang didengar di telinga dan menyalahkan dirinya. Makan, minum, mandi menjadi malas dan harus diingatkan keluarga. Tidak mau bersosialisasi, hanya di kamar. Waktu luang hanya melamun, tidak mau melakukan pekerjaan rumah maupun luar rumah. 
Setelah dilakukan penatalaksanaan sesuai protokol, maka didapatkan nilai HAM-D I: 25, HAMD II: 5, dan HAM-D III: 4.

\section{PASIEN V, Sdr NS ( 27 tahun)}

Pasien datang ke Rumah Sakit dengan keluhan utama sering melamun, mudah marah $\&$ kesulitan tidur. Berdasarkan informasi yang dikumpulkan didapatkan keterangan bahwa sekitar 1 bulan yang lalu pasien mengalami perubahan tingkah laku berupa tampak pendiam, tidak semangat, sering melamun, pasien sering mengalami gangguan tidur. 2 minggu terakhir. Pasien tampak bingung, sering minta maaf pada orang-orang disekelilingnya. Selain itu, pasien menjadi sedih karena merasa banyak dosa dan bersalah. Pasien bicara sendiri dan marah-marah tanpa sebab karena mendengar suarasuara menyalahkan \& memerintah pada pasien. Sehari-hari pasien sering menyendiri, jarang mau makan.

Setelah dilakukan penatalaksanaan sesuai protokol, maka didapatkan nilai HAM-D I: 29, HAMD II: 15, dan HAM-D III: 9.

Dari hasil penilaian HAM-D pertama sampai dengan yang ketiga pada keseluruhan pasien, maka dapat digambarkan pada Gambar 1.

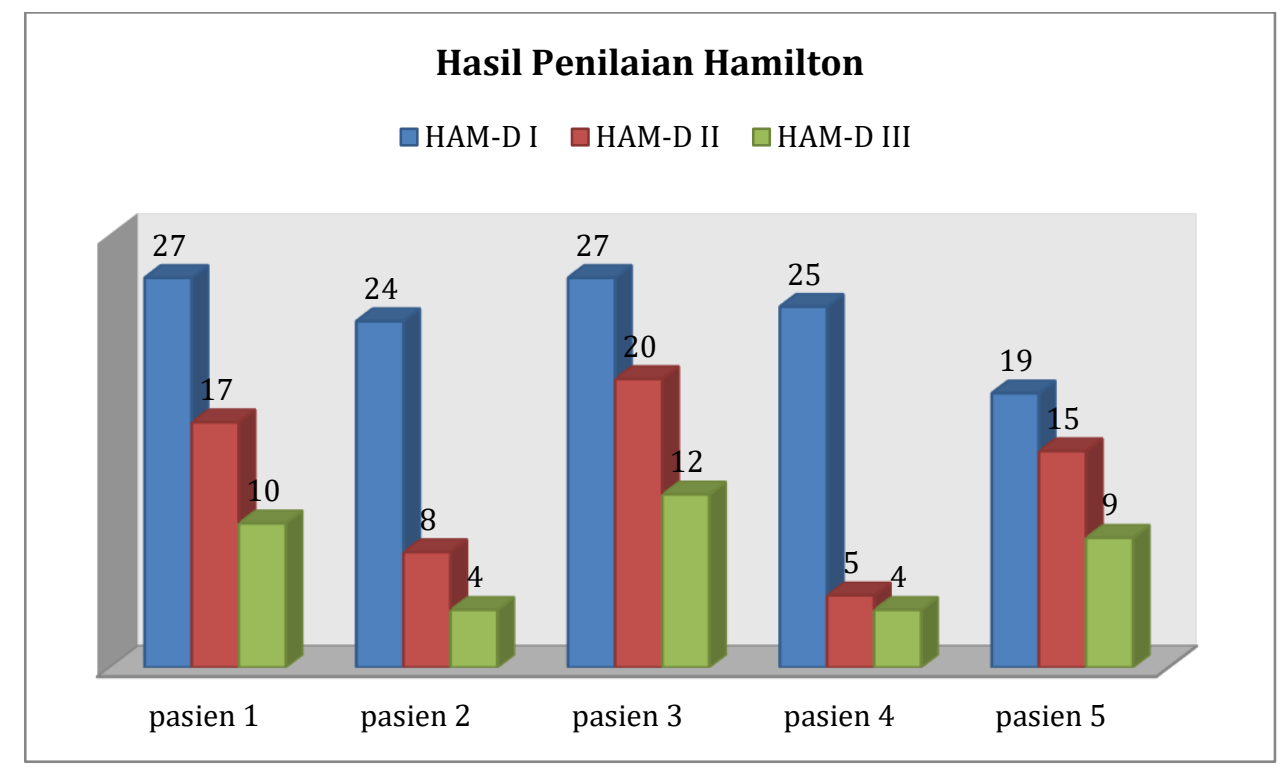

Gambar 1. Hasil penilaian HAM-D pertama sampai dengan yang ketiga pada keseluruhan pasien.

\section{KESIMPULAN}

Pada pasien-pasien ini menunjukkan bahwa angka HAM-D pertama sampai dengan ketiga menunjukkan penurunan, sehingga disimpulkan bahwa penggunaan rTMS pada penderta depresi mayor dapat memperbaiki gejala yang dideritanya.

\section{REKOMENDASI}

Dilakukan penelitian lebih lanjut dengan lebih memperhatikan berbagai faktor pengganggu (confounding factor) dengan jumlah sample yang lebih banyak. 


\section{DAFTAR PUSTAKA}

1. Sadock BJ, Sadock VA, Kaplan \& Sadock's Synopsis of Psychiatry: Behavioral Sciences/ Clinical Psychiatry, 10th Edition, Lippincott Williams \& Wilkins, New York, 2007.

2. DSM-5/ American Psychiatric Association, Diagnostic and Statistical Manual of Mental Disorders, $7^{\text {th }}$ Edition, American Psychiatric Publishing, Washington DC, 2013.

3. WHO cit Amir, Depresi: Aspek Neurobiologi, Diagnostik, dan Tatalaksana, Edisi Kedua, Badan Penerbit FKUI, Jakarta, 2001.

4. Christodoulou, Depression A Global Crisis: Depression a consequence of the economic crisis, Word Federation for Mental Health, http://www.who.int, 2012.

5. Amir, Depresi: Aspek Neurobiologi, Diagnostik, dan Tatalaksana, Edisi Kedua, Badan Penerbit FKUI, Jakarta, 2016.

6. Gelenberg AJ, Freeman MP, Markowitz JC, Rosebaum JF, Thase ME, Trivedi MH, Rhoads
RS, Practice Guideline for The Treatment of Patients with Major Depressive Disorder, 3th Edition, American Association, USA, 2010.

7. Padberb et all cit Lisanby, Brain Stimulation in Psychiatric Treatment, $1^{\text {st }}$ Edition, American Psychiatric Publishing Inc, Washington DC, 2004.

8. Dell'Osso B, Camuri G, Castellano F, Vecchi V, Benedetti $\mathrm{M}$, Bortolussi S, Altamura AC, Meta-Review of Metanalytic Studies with Repetitive Transcranial Magnetic Stimulation (rTMS) for the Treatment of Major Depression, http://www.ncbi.nih.gov, 2011.

9. Goerge et all cit Lisanby, Brain Stimulation in Psychiatric Treatment, $1^{\text {st }}$ Edition, American Psychiatric Publishing Inc, Washington DC, 2004.

10. Klein et all cit Lisanby, Brain Stimulation in Psychiatric Treatment, $1^{\text {st }}$ Edition, American Psychiatric Publishing Inc, Washington DC, 2004. 